\title{
Teaching NeuroImages: Gummatous neurosyphilis
}

\section{An atypical presentation in a patient with HIV}

Helena Sá e Silva, MD, Catarina O. Paulo, MD, Frederico Duarte, MD, Ricardo C. Abreu, MD, Isabel Neves, MD, and Pedro Moniz, MD

Neurology ${ }^{\circledR}$ 2018;90:e913-e914. doi:10.1212/WNL.0000000000005058

\section{Correspondence}

Dr. Sá e Silva

helena.saesilva@gmail.

com

Figure MRI features of gummatous neurosyphilis pretreatment and posttreatment


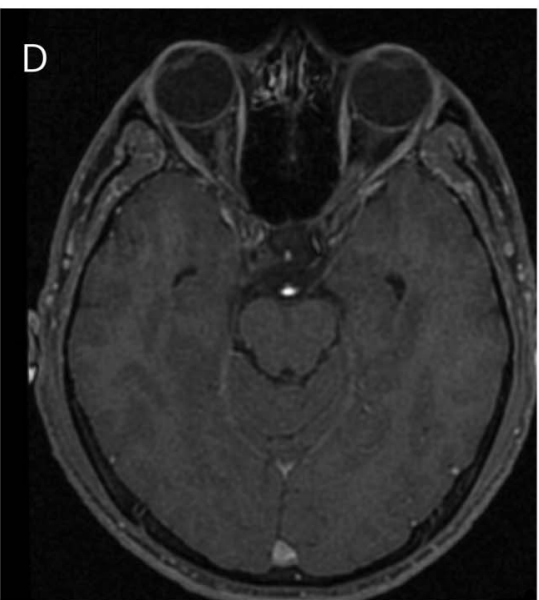

(A) Axial T2 MRI shows diffuse thickening of the cisternal portion of the right oculomotor nerve. (B) Contrasted T1 MRI exhibits strong enhancement of the lesion. (C) Axial T2 MRI and (D) contrasted T1 MRI demonstrate complete radiographic resolution 4 months after treatment.
A 29-year-old HIV-infected man, on antiretroviral treatment with negative viral load and a low CD4+ T-cell count $\left(344 / \mathrm{mm}^{3}\right)$, presented with right eyelid ptosis and diplopia. On examination, right pupil was dilated, without reaction to light or accommodation. Extraocular movements were impaired in all directions, except abduction.

Serum venereal disease research laboratory (VDRL) and Treponema pallidum hemagglutination (TPHA) were positive (titer of $1 / 512$ and $1 / 10,240$, respectively), confirmed in CSF:

\section{MORE ONLINE}

$\rightarrow$ Download teaching slides

links.lww.com/WNL/A300

From the Department of Neuroradiology (H.S.e.S., P.M.) and Infectious Diseases Unit (C.O.P., F.D., R.C.A., I.N.), Hospital Pedro Hispano, Matosinhos Local Health Unit, Portugal. Go to Neurology.org/N for full disclosures. Funding information and disclosures deemed relevant by the authors, if any, are provided at the end of the article. 
VDRL positive, TPHA titer of $1 / 320$ with $92 / \mu \mathrm{L}$ mononuclear cells, $55 \mathrm{mg} / \mathrm{dL}$ of protein, normal glucose.

MRI showed an enlarged and enhancing right oculomotor nerve (figure, A and B). The patient was treated with a 2-week course of penicillin with complete radiographic resolution (figure, $\mathrm{C}$ and D) and partial clinical recovery. ${ }^{1}$ Although very rare, neurosyphilis can affect the cranial nerves and should be suspected in a coinfected patient with HIV. ${ }^{2}$

\section{Author contributions}

Helena Sá e Silva: manuscript concept and design, acquisition of imaging data, analysis and interpretation of data. Catarina Oliveira Paulo: manuscript concept and design, acquisition of clinical data, analysis and interpretation of data. Frederico Duarte: acquisition of clinical data, analysis and interpretation of data. Ricardo Correia Abreu: acquisition of clinical data, analysis and interpretation of data, critical revision of manuscript for intellectual content. Isabel Neves: acquisition of clinical data, analysis and interpretation of data, critical revision of manuscript for intellectual content. Pedro Moniz: manuscript concept and design, analysis and interpretation of data, critical revision of manuscript for intellectual content.

\section{Study funding}

No targeted funding reported.

\section{Disclosure}

The authors report no disclosures relevant to the manuscript. Go to Neurology.org/N for full disclosures.

\section{References}

1. Seeley WW, Venna N. Neurosyphilis presenting with gummatous oculomotor nerve palsy. J Neurol Neurosurg Psychiatry 2004;75:789.

2. Hess CW, Rosenfeld SS, Resor SR Jr. Oculomotor nerve palsy as the presenting symptom of gummatous neurosyphilis and human immunodeficiency virus infection: clinical response to treatment. JAMA Neurol 2013;70:1582-1583. 


\section{Neurology}

\section{Teaching NeuroImages: Gummatous neurosyphilis: An atypical presentation in a patient with HIV \\ Helena Sá e Silva, Catarina O. Paulo, Frederico Duarte, et al. Neurology 2018;90;e913-e914 \\ DOI 10.1212/WNL.0000000000005058}

\section{This information is current as of March 5, 2018}

\section{Updated Information \&} Services

References

Subspecialty Collections

Permissions \& Licensing

Reprints including high resolution figures, can be found at: http://n.neurology.org/content/90/10/e913.full

This article cites 2 articles, 1 of which you can access for free at: http://n.neurology.org/content/90/10/e913.full\#ref-list-1

This article, along with others on similar topics, appears in the following collection(s):

Cerebrospinal Fluid

http://n.neurology.org/cgi/collection/cerebrospinal_fluid HIV

http://n.neurology.org/cgi/collection/hiv

MRI

http://n.neurology.org/cgi/collection/mri

Ocular motility

http://n.neurology.org/cgi/collection/ocular_motility

Information about reproducing this article in parts (figures,tables) or in its entirety can be found online at:

http://www.neurology.org/about/about_the_journal\#permissions

Information about ordering reprints can be found online:

http://n.neurology.org/subscribers/advertise

Neurology ${ }^{\circledR}$ is the official journal of the American Academy of Neurology. Published continuously since 1951, it is now a weekly with 48 issues per year. Copyright (O) 2018 American Academy of Neurology. All rights reserved. Print ISSN: 0028-3878. Online ISSN: 1526-632X.

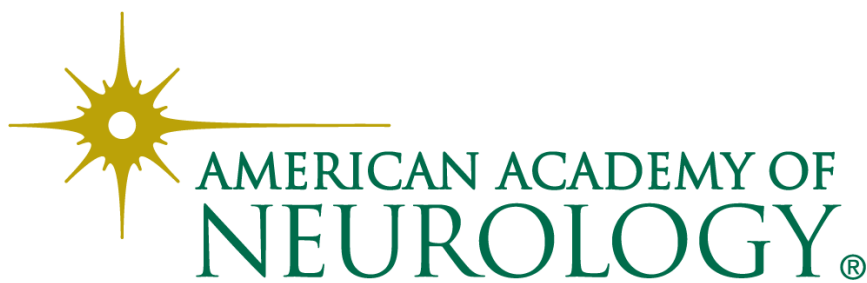

